\title{
Ternstroemia cameroonensis (Ternstroemiaceae), a new medicinally important species of montane tree, nearly extinct in the Highlands of Cameroon
}

\author{
M. Cheek ${ }^{1}$, B. Tchiengue ${ }^{2}$, W.N. Tacham ${ }^{3}$
}

\section{Key words}

Cloud Forest

Critically Endangered

medicinal plant

Pentaphylacaceae

Theaceae

\begin{abstract}
Ternstroemia cameroonensis sp. nov. (Ternstroemiaceae) is formally described from the Highlands of Cameroon and its conservation status is assessed as Critically Endangered using the IUCN 2012 standard. This is the third species of Ternstroemia known from Africa. The species is unusual in its genus in being monoecious, having Terminalia-branching (Aubreville's model), phyllotaxy of 1/3 (not pseudo-verticillate), flowers with a uniseriate androecium and a distinct intra-staminal disc, and in the stamens lacking a distinct apicular connective. The species is used locally for extensive medicinal purposes.
\end{abstract}

Published on 23 March 2017

\section{INTRODUCTION}

René Letouzey was the most far-ranging and prolific of all the field botanists of Cameroon. On 29 November 1974 he came across a mysterious tree in flower and fruit in a remnant forest patch in the Cameroon Highlands. He collected specimens near the settlement of Fossimondi, in present-day SW Region of Cameroon, as Letouzey 13380, considering it to be a Flacourtiaceae.

H. Sleumer later identified the specimen (in litt., YA, det. 1975) as Ternstroemia polypetala Melch. (then placed in Theaceae), a species hitherto only known from the area of the Uluguru Mts of the Eastern Arc Highlands of Tanzania (Melchior 1934, Verdcourt 1962, Letouzey 1977). Later it was discovered from adjoining northern Malawi (White et al. 2001). This was another case of a remarkable montane range disjunction, comparable with that of, e.g., Alchemilla fischeri Engl., first discovered on several peaks of Kenya, before being found by Letouzey near the summit of Mt Oku in NW Region of Cameroon, the populations separated from each other by almost the whole width of central Africa (Cheek et al. 2000).

Twenty years later the first author, seeking to identify a strange tree from a fruiting specimen collected near the forests of ljim by Martin Etuge (Etuge 3557) in 1996 as part of an inventory of species for the intended 'Plants of Mt Oku and the ljim Ridge' (Cheek et al. 2000), discovered it to be the same taxon as Letouzey's. This prompted a re-assessment of the Cameroonian material: was it really conspecific with that from Tanzania? The conclusion after careful comparison with the Tanzanian material was that there are sufficient morphological differences to justify erection of a new species for the Cameroonian material named below as Ternstroemia cameroonensis Cheek. Many of the characters separating the two species (see Table 1) were first elucidated by Letouzey (1977). Letouzey may have published his specimen as a new species or subspecies had

\footnotetext{
Science, Royal Botanic Gardens, Kew, TW9 3AE, UK;

corresponding author e-mail: m.cheek@kew.org

2 IRAD-National Herbarium of Cameroon, Yaoundé, BP 1601, Cameroon.

${ }^{3}$ Faculty of Sciences, University of Bamenda, P.O. Box 39, Bamenda, NW Region, Cameroon.
}

he not been influenced by Sleumer's determination and by the fact that only a single gathering from a single plant was available to him (Letouzey 1977).

Realising that the putative new species was extremely rare and threatened, the first author sought to obtain its protection. Etuge was requested to return in 1999 to the site at ljim at which he had collected Etuge 3557, so as to refind the tree. This resulted in the discovery that the tree had been cut down, and that the forest patch in which it had grown had been reduced by two thirds. Searches for the Ternstroemia over two days in the ljim area by a large team of botanists, including Etuge, failed to find another plant of the species (Cheek in Cheek et al. 2000: 74-75). The second author, leading teams conducting a botanical survey of the Lebialem Highlands (Harvey et al. 2010) near to the Letouzey site at Fossimondi, made several attempts between 2002 and 2005 to rediscover Letouzey's forest patch and to refind the Ternstroemia, but failed and concluded that it also had been destroyed (Pearce in Harvey et al. 2010: 43). Intensive botanical surveys in other surviving highland forest areas of the Cameroon Highlands over 1997-2011 also failed to find any sign of Ternstroemia (Cable \& Cheek 1998, Cheek et al. 2004, 2010, Harvey et al. 2004, 2010). There was every reason to think that the Ternstroemia was extinct and therefore that there was no urgency to describe it as new.

However, in 2013 the third author, a researcher in traditional medicinal plants, already familiar with the species in the wild since 2002, brought a sample (Tacham s.n.) for botanical identification to the National Herbarium of Cameroon (YA). Here it was identified by the second author as the new Ternstroemia, not, after all, extinct. The second and third authors made a joint visit to the only known surviving population in May 2015. The site seemed to be close to the original Letouzey site but not identical with it, supported by the composition of associated species at the two sites being different.

The genus Ternstroemia is pantropical with c. 100 species. Most of the species occur in tropical and subtropical Americas, with others in S and E Asia (Stevens 2001 onwards, Weitzman et al. 2004). Only two species have been recognised from Africa and none from Madagascar (Weitzman et al. 2004). Ternstroemia 
Table 1 Characters separating Ternstroemia cameroonensis from Ternstroemia polypetala (data on last taxon from Verdcourt 1962).

\begin{tabular}{lll}
\hline & Ternstroemia polypetala & Ternstroemia cameroonensis \\
\hline Breeding system & Dioecious & Monoecious \\
$\begin{array}{l}\text { Percentage of the leaf length from the base at } \\
\text { which occurs the widest point of leaf blade }\end{array}$ & $70-75 \%-65 \%$ \\
Quaternary nerves & Conspicuous, reticulate & Absent \\
Androecium & Multiseriate & Uniseriate \\
Apical anther appendage & $0.25-1$ times as long as anther & Absent \\
Pedicel length at anthesis & $20-30 \mathrm{~mm}$ & 8-13 mm \\
Intrastaminal disc & Absent & Present in female flowers \\
\hline
\end{tabular}

africana Melch. is known from the littoral from north of the Congo River to the Niger, and T. polypetala from the Uluguru Mts of Tanzania to northern Malawi (White et al. 2001). The genus was formerly included in Theaceae together with Ficalhoa Hiern (now usually placed in Sladeniaceae), e.g., in Verdcourt (1962). Ternstroemia is now placed in Ternstroemiaceae (Ericales) together with Balthasaria Verdc. (also Tropical Africa) and in Macaronesia Visnea L.f. (Weitzman et al. 2004). The remaining nine genera of Ternstroemiaceae occur mainly in Tropical Asia, but with two genera restricted to the Neotropics (Weitzman et al. 2004). By some Ternstroemiaceae is merged with Pentaphylacaceae where the latter unfortunately takes preference (nom. cons.) (Stevens 2001 onwards, Culham 2007). However, the sister relationship of Ternstroemiaceae and Pentaphylacaceae and hence the possibility to merge them is quite uncertain (Stevens pers. comm.).

\section{MATERIALS \& METHODS}

All specimens cited have been seen by the authors unless indicated n.v. Herbarium citations follow Index Herbariorum (Thiers et al. continuously updated) and binomial authorities IPNI (continuously updated). The conservation assessment was made using the categories and criteria of IUCN (2012). Herbarium material was examined with a Leica Wild M8 dissecting binocular microscope fitted with an eyepiece graticule measuring in units of $0.025 \mathrm{~mm}$ at maximum magnification. The drawing was made with the same equipment using Leica 308700 camera lucida attachment.

\section{KEY TO THE SPECIES OF AFRICAN TERNSTROEMIA}

1. With Terminalia-branching; of inland mountains; style minute $\ldots \ldots \ldots \ldots \ldots \ldots \ldots \ldots \ldots \ldots \ldots 2$

1. Lacking Terminalia-branching; of coastal, lowland habitats; flower with style long and slender . . . . . . . T. africana

2. Pedicel 20-30 mm long at anthesis; bracts alternate, triangular, as long, or longer than wide; Tanzania and Malawi . . . . . . . . . . . . . . . . . . . . . . . . polypetala

2. Pedicel 8-12 mm long at anthesis; bracts opposite, transversely elliptic, broader than long; Cameroon . . . . . . . . . ..................... cameroonensis

Ternstroemia cameroonensis Cheek, sp. nov. - Fig. 1

Ternstroemia polypetala sensu Letouzey (Letouzey (1977) 6; Cheek in Cheek et al. (2000) 165; Cheek (2000a)).

Ternstroemia sp. nov. Cheek (Cheek \& Onana (2011) 8, f. 4; Onana (2011) 147; (2013) 208).

Similar to Ternstroemia polypetala Melch. but differs in the shorter pedicel length (8-13 mm long at anthesis, not 20-30 mm), the bracts which are opposite or nearly opposite, immediately adjacent to the calyx, 2 times broader than long, apex rounded (not alternate, clearly separated from each other by $1-8 \mathrm{~mm}$, the most distal usually inserted several $\mathrm{mm}$ below the calyx, usually triangular and as long as broad, or longer); venation of mature leaves not reticulate, lacking visible quaternary nerves (not finely reticulate with conspicuous quaternary nerves); androecium in female flowers uniseriate (not multiseriate), stamens lacking an apiculus (not with a long conspicuous apiculus). - Type: Letouzey 13380 (holotype K; isotypes BM, L L.2400388, P n.v., YA, Wood CTFT, Montpellier), Cameroon (South West Region), 'de la route de Baranka $(2400 \mathrm{~m})$ à la Chefferie de Fossimondi $(1700 \mathrm{~m})$ sur le massif de Bamboutos, à 25 km au Nord-Ouest de Dschang', fl. fr. 29 Nov. 1974.

Etymology. Cameroonensis signifying from Cameroon, which holds the only global location for this species.

Monoecious tree 10-15 m tall (Letouzey 13380), glabrous. Crown hemispherical, trunk up to $40 \mathrm{~cm}$ diam at $1.5 \mathrm{~m}$ from the ground, rough, red-brown, with raised pustules; slash thick, white-cream, oxidising red-brown or pink. Branches and branchlets curving upwards and terminating in clusters of leaves, developing according to Aubréville's crown model (Tomlinson 1987), that is with 'Terminalia-branching'; leafy branchlets terete, 2-3.5 mm diam, drying dull grey-brown and cracking in oblongs, often covered by crustose lichens; leafscars horseshoe-shaped, pale glossy brown, slightly raised, c. 1 by $1 \mathrm{~mm}$. New shoots probably arising in wet season (JuneOctober), of two types: 1) extension shoots (mainly vegetative, arising laterally from below the established plagiotropic main axes and arching below and then overtopping them; and 2) main shoots, a continuation of the established main axis.

1 Extension shoots (seen in Tchiengue s.n. collected in May) lack nodes in the proximal $35-50 \mathrm{~mm}$; the subsequent four internodes are (4-)9-10 mm long, with $1 / 3$ phyllotaxy (each leaf making a third of a circle from the previous). Usually sterile in the season in which they are produced, occasionally the basal node subtends a flower.

2 Main shoots with two stages in one season: a) the proximal 2-8 nodes (c. 2-9 $\mathrm{mm}$ long, internodes 1-2 $\mathrm{mm}$ long), producing small ('prophylls'), highly caducous reduced leaves falling before anthesis, oblanceolate $0.9-2.4$ by $0.4-0.8 \mathrm{~mm}$, each subtending 1-flowered inflorescences; b) the distal part of the shoots lacking flowers, with a rosette (internode lengths nil) of (3-)7-9(-12) larger, spirally inserted leaves that persist for $1-2$ years.

Leaves persisting 12 months or more (sometimes seen persisting on the previous seasons stems above fruits (Fig.1a2), spirally inserted, alternate, simple, leathery, thickness $0.3-0.5$ $\mathrm{mm}$ when dry, drying glossy black above, matt mid to dark brown below, elliptic, or elliptic-obovate (2.3-)5.0-7.2(-9) by (0.7-)1.7-2.8 cm, widest point $60-65 \%$ of the distance from the base of the blade, apex obtuse, then abruptly and shortly emarginate, less usually rounded, base gradually decurrent down the petiole as a tapering, narrow wing, sometimes reaching the stem; lateral nerves inconspicuous (7-)8-11 on each side of the midrib, brochidodromous, uniting $2-3 \mathrm{~mm}$ from the margin, tertiary nerves very sparse, quaternary nerves not visible; margin revolute, young leaves with up to ten patent, toothlike, short translucent, caducous, marginal glands on the proximal $1 / 4$ length of the blade and petiole, teeth $0.1-0.2(-0.4) \mathrm{mm}$ 

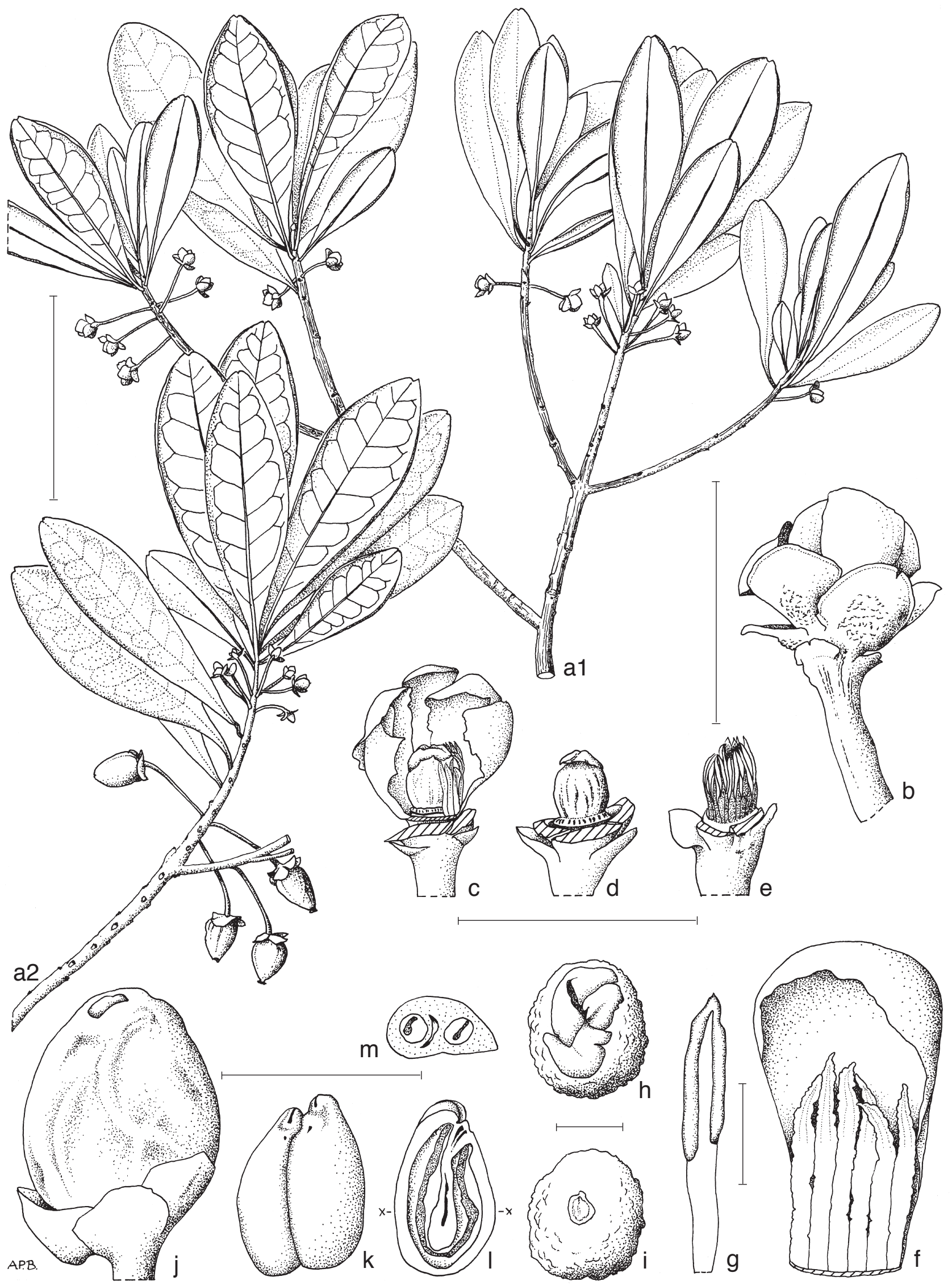

Fig. 1 Ternstroemia cameroonensis. a1. Habit, flowering branches; a2. habit, branch with fruit and flowers; b. female flower opening; c. female flower, side view, 5 sepals, 2 petals and part of the single whorl of staminodes removed to expose the ovary and its basal disc; $d$. female flower, all perianth lobes and staminodes removed; e. male flower, perianth segments removed; $f$. innermost petal of female flower showing adnate, flattened staminodes; g. stamen of male flower; h. ovary, apical view, showing 3-lobed, shallowly domed stigma; i. ovary, detail of h. but stigma removed to show the short style; j. fruit (slightly distorted by drying); k. two appressed seeds; I. seed in longitudinal section showing the U-shaped embryo; $m$. seed, transverse section along lines $x-x$ indicated in I (all: Letouzey $13380, \mathrm{~K})$. - Scale bars: $\mathrm{a} 1+\mathrm{a} 2=5 \mathrm{~cm} ; \mathrm{b}-\mathrm{e}, \mathrm{j}-\mathrm{m}=1 \mathrm{~cm} ; \mathrm{f}-\mathrm{i}=1 \mathrm{~mm}$. - Drawn by Andrew Brown. 
long. Petiole (0-)2-8 mm long, flat above with a narrow wing, and concave below, glabrous. Stipules absent. Pedicels developing singly in axils of reduced highly caducous leaves (see above), at anthesis with (1-)4-9(-11) flowers on the $5-10 \mathrm{~mm}$ of naked stem immediately below the terminal cluster of leaves; pedicels spreading, straight, stiff, 8-12(-13) by $(0.5-) 1(-1.5) \mathrm{mm}$, drying more or less 3 -angled, minutely papillate-verrucate, black. Bracts 2, subopposite, subequal, inserted more or less immediately below the calyx, orbicular, ovate or transversely rectangular, $0.7-1.8$ by $1.5-2 \mathrm{~mm}$, apex rounded to obtuse, base often with glandular areas. Flowers borne October-March (Tacham s.n.) with male (c. $12 \mathrm{~mm}$ long) and female (c. $9 \mathrm{~mm}$ long) on different branches of the same individual (Letouzey 13380). Sepals 5, yellow, imbricate, irregularly suborbicular, slightly concave, $2.5-3.5$ by $3.5 \mathrm{~mm}$, apex rounded, slightly revolute. Petals $7-8$, white on inner surface, imbricate, outermost petals with outer surface pink, obovate to shortly ligulate, apex hooded. Female flowers with the petals (3.2-) $6-7$ by $1.8-3 \mathrm{~mm}$, androecium uniseriate, the staminodes white, 30-35, forming a cylinder around the ovary; staminodes united to each other at the base and also adhering to the base of the petals (Fig. 1f), ligulate, flattened, 1.75-2.5 by $0.2-0.3 \mathrm{~mm}$, thecae not developed, apiculus absent or indistinct. Disc or torus (presumably nectariferous), $0.2 \mathrm{~mm}$ thick, surface flattened, with a ring of c. 35 small, regular depressions (Fig. 1d). Ovary pale yellow, ellipsoid, subverrucate 4 by $3 \mathrm{~mm}$, unilocular, ovules 3-5, inserted at the apex of the axile column. Stigma subsessile, 2(-3)-lobed, forming a shallow cap or dome over the apex of the ovary, c. $2 \mathrm{~mm}$ diam. Male flowers with the petals c. $9 \mathrm{~mm}$ long by c. $2-3 \mathrm{~mm}$ wide; stamens $35-40$, (Fig. 1e), more or less uniseriate, $2.8-3 \mathrm{~mm}$ long, dorsiventrally flattened $0.2-0.4 \mathrm{~mm}$ wide, the anther thecae inserted along the two lateral margins each 1.4-1.6 mm long, united at the apex, the connective not extended as an apiculus (Fig. $1 \mathrm{~g}$ ); filament c. 1-1.3 $\mathrm{mm}$ long, shorter than the staminal portion. Intrastaminal disc and ovary inconspicuous. Fruit ovoid, green-orange or yellow or orange, $1.2-2.2$ by $1-1.5 \mathrm{~cm}$, at length dehiscing, the pericarp falling to expose the bright red 1-2(-5)-seeds. Fruiting pedicel accrescent, c. 22 by $0.2 \mathrm{~cm}$, sepals accrescent, ovate to orbicular-elliptic, concave, c. 0.5 by $0.5 \mathrm{~cm}$, pericarp fleshy, c. $3 \mathrm{~mm}$ thick, styles persistent, flat, appressed to pericarp, c. 2 by $1.5 \mathrm{~mm}$ in plane view, matt grey. Seeds red at fruit dehiscence, when dried bony, pink to pale brown, laterally flattened ovoid, faceted by mutual compression where more than 1 per fruit, anatropous, $6-9$ by $4-6$ by $3-4$ $\mathrm{mm}$, with a longitudinal furrow between the U-shaped embryo ends; hilum circular, depressed, subapical and lateral to the boss-like radicle extension.

Distribution \& Ecology - Highlands of Cameroon, in SW and (formerly but probably now extinct) NW Regions. Upper submontane (cloud forest) and montane forest, with Nuxia congesta (Loganiaceae), Syzygium staudtii (Myrtaceae), Podocarpus milanjianus (Podocarpaceae), Prunus africana (Rosaceae) (cited on label of Letouzey 13380), Cassipourea gummiflua (Rhizophoraceae), Pentarrhinum abyssinicum subsp. ijimense (Asclepiadaceae) (collections associated with Etuge 3557), Rapanaea melanophloeos (Primulaceae), Schefflera sp. (Araliaceae) (Tchiengue s.n.); 1900-2300 m altitude.

Vernacular names \& Uses - Nkene (Bamumbu language). Medicinally much used (which has possibly contributed to its rarity) by the Mundani people of the Lebialem Highlands, e.g., for sexually transmitted diseases and as a blood tonic (Tacham s.n.), also to address female sterility (Tchiengue s.n.). According to Tacham et al. (2015), who list the species as Ternstroemia sp. nov., Nkene is one of 128 species used by the Mundani: "Decoction of bark is taken with milk for anemia and sickle cell. Concoction with bark of Trichilia is taken orally for pelvic inflammatory disease and infertility".
Additional specimens. CAMERoon, North West Region, below Lake Oku, on S, Kom side, Aboh-Zitum, fr. fl. buds, 21 Nov. 1996, Etuge 3557 (K, YA); South West Region, Lebialem Prefecture, Baranka, $2 \mathrm{~km}$ on road to Fossimondi, fl. fr., 15 Dec. 2013, Tacham s.n. (K, YA 3 sheets); ibid fl. fr., May 2015, Tchiengue s.n. (K, YA 5 sheets).

Conservation - We assess Ternstroemia cameroonensis as Critically Endangered ( $C R$ B2ab(iii)+D) according to the categories and criteria of IUCN (2012) since, despite widespread targeted searching over many years, only 10 mature individuals are known to survive (Criterion D). These are all at a single location (area of occupancy estimated as $4 \mathrm{~km}^{2}$ using the IUCN-preferred grid cells of this dimension) where there are ongoing losses of the habitat due to clearance of natural vegetation for agricultural land in the immediate area (Letouzey 1977, Tchiengue pers. obs. 1999-2015). Trees are known to have been exterminated at the type locality and at Mt Oku in the last few decades resulting in the loss of two of the three known sites for the species. Trees at the only surviving site are also threatened by wounds inflected by harvesting of bark for medicinal purposes. Tacham et al. (2015) report that the species is overexploited for sale locally and in neighbouring markets. No regeneration has been detected at this site (Tchiengue pers. obs. 2015), possibly because any seedlings that develop might be swept away by run-off down the steep slopes on which the surviving trees grow. The species has not been cultivated nor seed-banked, although we intend to rectify this. A poster depicting the species, for use in Cameroon promoting its conservation, was produced and distributed by Kew (Cheek 2000a).

Ternstroemia polypetala in the broad sense, including the Cameroon population, as well as those of Tanzania and Malawi, was assessed as Vulnerable by Lovett \& Clarke (1998), while it was assessed as Critically Endangered in Cheek et al. 2000: 74. The new species did not feature in the Red Data Book of Cameroon Flowering Plants (Onana \& Cheek 2011) since by that time it was recognised to be a separate species but lacked a published name which is required by IUCN before a conservation assessment can be accepted. Ternstroemia cameroonensis (as Ternstroemia sp. nov. sensu Cheek), was listed as Data Deficient (Onana 2013: 208).

\section{New species from the Highlands of Cameroon}

Ternstroemia cameroonensis is the most recent of numerous new species to science discovered and published from the Cameroon Highlands in recent years. Most of these are also threatened with extinction due to clearance of their habitat. Others include: Allophylus ujori Cheek (Cheek \& Etuge 2009a), Ancistrocladus grandiflorus Cheek (2000b), Brachystephanus kupeensis Champl. (Champluvier \& Darbyshire 2009), Chassalia laikomensis Cheek (Cheek \& Csiba 2000), Coffea montekupensis Stoff. (Stoffelen et al. 1997), Coffea bakossii Cheek \& Bridson (Cheek \& Bridson 2002), Cola metallica Cheek (2002), Coleochloa domensis Muasya \& D.A.Simpson (Muasya et al. 2010), Costus kupensis Maas \& H.Maas (Maas et al. 2016), Deinbollia oreophila Cheek (Cheek \& Etuge 2009b), Diospyros kupensis Gosline \& Cheek (1998); Dovyalis cameroonensis Cheek \& Ngolan (2007), Dracaena kupensis Mwachala et al. (2007), Impatiens etindensis Cheek \& Eb.Fisch. (1999), Impatiens frithii Cheek (Cheek \& Csiba 2002b), Isoglossa dispersa I.Darbysh. (Darbyshire et al. 2011), Kupea martinetugei Cheek \& S.A.Williams (Cheek et al. 2003), Ledermanniella onanae Cheek (2003), Ledermanniella pollardiana Cheek \& Ameka (2008), Mussaenda epiphytica Cheek (2009), Myosotis cameroonensis Cheek \& R.Becker (2004), Newtonia duncanthomasii Mackinder \& Cheek (2003), Oxyanthus okuensis Cheek \& Sonké (2000), Psychotria geophylax and $P$. bakossiensis (Cheek \& Sonké 2005), Psychotria moseskemei Cheek (Cheek \& Csiba 2002a), Rhaptopetalum geophylax 
Cheek \& Gosline (in Cheek et al. 2002) and Talbotiella bakossiensis Cheek (Mackinder et al. 2010). Most of these are endemics of single mountains, sometimes of neighbouring peaks, and have putative sister species from lowland forest elsewhere within Cameroon or in central Africa. In rare cases the sister taxa are in the Eastern Arc Mountains of Tanzania (Kupea), or in the mountains of the eastern rift (Luzula). However, in most cases there is an absence of solid phylogenetic data to assign sister relationships.

Acknowledgements The first author thanks Earthwatch for supporting the fieldwork, and the Darwin Initiative of DEFRA, the UK Government for support to the Western Cameroon Biodiversity project and the Red Data Book of Cameroon project (2006-2011) all of which brought this species and its plight to our attention, and the last of which funded a research visit of the second author to Royal Botanic Gardens, Kew during which collaboration on this paper began. The Bentham-Moxon fund of Royal Botanic Gardens, Kew supported the visit of the first author to YA during which this paper was largely completed. Dr Ngo Ngwe and Dr Onana, present and past Heads of YA are thanked for their hospitality. George Gosline and two anonymous external reviewers made helpful comments on an earlier version of the paper.

\section{REFERENCES}

Cable S, Cheek M. 1998. The plants of Mt Cameroon. A conservation checklist. Royal Botanic Gardens, Kew. London

Champluvier D, Darbyshire I. 2009. A revision of the genera Brachystephanus and Oreacanthus (Acanthaceae) in tropical Africa. Systematics and Geography of Plants 79, 2: 115-192.

Cheek M. 2000a. Ternstroemia polypetala poster. Royal Bontanic Gardens, Kew.

Cheek M. 2000b. A synoptic revision of Ancistrocladus (Ancistrocladaceae) in Africa, with a new species from western Cameroon. Kew Bulletin 55: 871-882.

Cheek M. 2002. Three new species of Cola (Sterculiaceae) from western Cameroon, Cameroon. Kew Bulletin 57: 402-415.

Cheek M. 2003. A new species of Ledermanniella (Podostemaceae) from western Cameroon. Kew Bulletin 58: 733-737.

Cheek M. 2009. Mussaenda epiphytica sp. nov. (Rubiaceae) an epiphytic shrub from cloud forest of the Bakossi Mts, western Cameroon. Nordic Journal of Botany 27, 6: 456-459.

Cheek M, Ameka G. 2008. Ledermanniella pollardiana sp. nov. (Podostemaceae) from western Cameroon. Nordic Journal of Botany 26: 214-217.

Cheek M, Becker R. 2004. A new species of Myosotis L. (Boraginaceae) from Cameroon, with a key to the Tropical African species of the genus. Kew Bulletin 59: 227-231.

Cheek M, Bridson D. 2002. A new species of Coffea (Rubiaceae) from western Cameroon. Kew Bulletin 57: 675-680.

Cheek M, Csiba L. 2000. A new species and new combination in Chassalia (Rubiaceae) of western Cameroon. Kew Bulletin 55: 883-888.

Cheek M, Csiba L. 2002a. A revision of the Psychotria chalconeura complex (Rubiaceae) in Guineo-Congolian Africa. Kew Bulletin 57: 375-387.

Cheek M, Csiba L. 2002b. A new epiphytic species of Impatiens (Balsaminaceae) from western Cameroon. Kew Bulletin 57, 3: 669-674.

Cheek M, Etuge M. 2009a. Allophylus conraui (Sapindaceae) reassessed and Allophylus ujori described from western Cameroon. Kew Bulletin 64, 3: 495-502

Cheek M, Etuge M. 2009b. A new submontane species of Deinbollia (Sapindaceae) from Western Cameroon and adjoining Nigeria. Kew Bulletin 64, 3: 503-508.

Cheek M, Fischer E. 1999. A tuberous and epiphytic new species of Impatiens (Balsaminaceae) from Southwest Cameroon. Kew Bulletin 54, 2: 471-475.

Cheek M, Gosline G, Csiba L. 2002. A new species of Rhaptopetalum (Scytopetalaceae) from western Cameroon. Kew Bulletin 57, 3: 661-667.

Cheek M, Harvey Y, Onana J-M. 2010. The plants of Dom, Bamenda Highlands, Cameroon. A conservation checklist. Royal Botanic Gardens, Kew. London.

Cheek M, Ngolan R. 2007. A reassessment of the Dovyalis spinosissima Gilg (Flacourtiaceae) complex in Africa, with a new species from Cameroon. Kew Bulletin 61: 595-600. Stable URL: http://www.jstor.org/stable/20443304.

Cheek M, Onana J-M. 2011. Red Data plant species in Cameroon. A guide for secondary school teachers. Royal Botanic Gardens, Kew.

Cheek M, Onana J-M, Pollard BJ. 2000. The plants of Mount Oku and the ljim Ridge, Cameroon. A conservation checklist. Royal Botanic Gardens, Kew, London.
Cheek M, Pollard BJ, Darbyshire I, et al. 2004. The plants of Kupe, Mwanenguba and the Bakossi Mountains, Cameroon. A conservation checklist. Royal Botanic Gardens, Kew, London.

Cheek M, Sonké B. 2000. A new species of Oxyanthus (Rubiaceae-Gardeniinae) from western Cameroon. Kew Bulletin 55: 889-893.

Cheek M, Sonké B. 2005. Two further new species of Psychotria (Rubiaceae) from western Cameroon. Kew Bulletin 60: 293-300. Stable URL: http:// www.jstor.org/stable/4110940.

Cheek M, Williams S, Etuge M. 2003. Kupea martinetugei, a new genus and species of Triuridaceae from western Cameroon. Kew Bulletin 58: 225-228.

Culham A. 2007. Pentaphylacaceae. In: Heywood VH, et al., Flowering plant families of the world: 248-249. Firefly, London.

Darbyshire I, Pearce L, Banks H. 2011. The genus Isoglossa (Acanthaceae) in west Africa. Kew Bulletin 66, 3: 425-439.

Gosline G, Cheek M. 1998. A new species of Diospyros (Ebenaceae) from Southwest Cameroon. Kew Bulletin 53, 2: 461-465.

Harvey YB, Pollard BJ, Darbyshire I, et al. 2004. The plants of Bali Ngemba Forest Reserve, Cameroon. A conservation checklist. Royal Botanic Gardens, Kew, London.

Harvey YB, Tchiengue B, Cheek M. 2010. The Plants of the Lebialem Highlands, Cameroon. A conservation checklist. Royal Botanic Gardens, Kew, London.

IPNI (continuously updated).The International Plant Names Index. http:// ipni.org/.

IUCN. 2012. IUCN Red List categories and criteria: Version 3.1. Second edition. Gland, Switzerland and Cambridge, UK: IUCN. Available from: http://www.iucnredlist.org/ [accessed: Jan. 2017]

Letouzey R. 1977. Présence de Ternstroemia polypetala Melchior (Théacées) dans les Montagnes Camerounaises. Adansonia série 2, tome 17, fascicule 1: 5-10.

Lovett J, Clarke G.P. 1998. Ternstroemia polypetala. The IUCN Red List of threatened species 1998: e.T34877A9895086. http://dx.doi.org/10.2305/ IUCN.UK.1998.RLTS.T34877A9895086.en. Downloaded on 12 Feb. 2017.

Maas-van de Kamer H, Maas PJM, Wieringa JJ, et al. 2016. Monograph of African Costus. Blumea 61: 280-318.

Mackinder B, Cheek M. 2003. A new species of Newtonia (LeguminosaeMimosoideae) from Cameroon. Kew Bulletin 58: 447-452.

Mackinder B, Wieringa JJ, Van der Burgt XM. 2010. A revision of the genus Talbotiella Baker f. (Caesalpinioideae: Leguminosae). Kew Bulletin 65, 3: 401-420.

Melchior H. 1934. Die Theaceae des tropischen Afrikas. Notizblatt des Konige Botanische Garten Berlin 9: 1093-1100.

Muasya A, Harvey YH, Cheek M, et al. 2010. A new species of epiphytic Coleochloa (Cyperaceae) from Cameroon. Kew Bulletin 65: 1-3.

Mwachala G, Cheek M, Fischer E, et al. 2007. A new species of Dracaena L. (Ruscaceae) from Cameroon. Kew Bulletin 62: 613-616. Stable URL: http://www.jstor.org/stable/20443393.

Onana J-M. 2011. The vascular plants of Cameroon. A taxonomic checklist with IUCN assessments. Flore Du Cameroun 39.

Onana J-M. 2013. Synopsis des Espèces Végétales Vasculaires Endémique et Rares du Cameroun. Check-liste pour la gestion durable de la conservation de la biodiversité. Flore Du Cameroun 40. MINRESI, Cameroun.

Onana J-M, Cheek M. 2011 Red data book of the flowering plants of Cameroon: IUCN Global Assessments. Royal Botanic Gardens, Kew.

Stevens PF. 2001 onwards. Angiosperm phylogeny website. Version 12, July 2012 [and more or less continuously updated since]. http://www.mobot.org/ MOBOT/research/APweb/.

Stoffelen P, Cheek M, Bridson D, et al. 1997. A new species of Coffea (Rubiaceae) and notes on Mt Kupe (Cameroon). Kew Bulletin 52, 4: 989-994. Tacham WN, Fonge BN, Fonkou T. 2015. Traditional medicine and ethnobotanical use of wild plants by the Mundani people of Wabane, South West Region, Cameroon. The Journal of Ethnobiology and Traditional Medicine. Photon 125: 1060-1080.

Thiers B (continuously updated). Index Herbariorum: A global directory of public herbaria and associated staff. New York Botanical Garden's Virtual Herbarium. Available from: http://sweetgum.nybg.org/ih/ [accessed: Jan. 2017].

Tomlinson PB. 1987. Architecture of tropical plants. Annual Review of Ecology and Systematics 18: 1-21.

Verdcourt B. 1962. Theaceae. In: Hubbard CE, Milne-Redhead E (eds), Flora of Tropical East Africa: 1-8. Crown Agents for Overseas Governments \& Administrations, London.

Weitzmann AL, Dressler S, Stevens PF. 2004. Ternstroemiaceae. In: Kubitzki $\mathrm{K}$ (ed.), Flowering plants. Dicotyledons. Celastrales, Oxalidales, Rosales, Cornales, Ericales. The families and genera of vascular plants VI: 450-460. Springer Verlag.

White F, Dowsett-Lemaire F, Chapman JD. 2001. Evergreen Forest Trees of Malawi. Royal Botanic Gardens, Kew. 